Ann. Biol. anim. Bioch. Biophys., 1977, 17 (5 A), 713-721.

\title{
Effect of temperature on the growth and fertility of the field-vole, Microtus arvalis, raised in different daylength and feeding conditions
}

\author{
Marie-José DAKETSE *, Lise MARTINET ** \\ Station de Physiologie animale, I. N. R. A., \\ 78350 Jouy-en-josas, France
}

Summary. This report studies the effects of 3 temperatures $\left(5^{\circ} \mathrm{C}, 22^{\circ} \mathrm{C}\right.$ or $\left.33^{\circ} \mathrm{C}\right)$ and their interaction with daily daylength ( $15 \mathrm{~h}$ or $10 \mathrm{~h}$ per $24 \mathrm{~h}$ ) ano the date of alfalfa harvest (april or june) on growth and fertility of the field-vole from birth to 45 days.

Body growth and fertility decrease inversely with the temperature. When added to a short daylight ratio $(10 \mathrm{~h})$, hot ambient temperature has an unfavorable effect on fertility ; clfalfa harvested late in the year plus the short daylength also adversely affect body growth and fertility.

At 35 days in females and at 45 days in moles, the largest and most fertile animals are those raised of $5^{\circ} \mathrm{C}$ under a long daylight ratio and fed alfalfa harvested in april. On the other hand, the smallest and least fertile animals are raised at $33^{\circ} \mathrm{C}$ under a short daylength and fed alfalfa harvested in june.

The synergic effects of the three factors studied can therefore explain the seasonal cycles of growth and fertility in the field-vole.

The field-vole, Microtus arvalis, has a seasonal reproduction cycle generally extending from february to october (Delost, 1955 ; Martinet, 1967). In mild winters some sexually active individuals have been observed (Microtus arvalis : Stein, 1952 ; agrestis : Raynaud, 1951 ; californicus : Greenwald, 1957). Moreover, reproduction stops or fertility is lower in some hot regions in the summer; this is the case of Microtus guentheri in Palestine (Bodenheimer, 1949) or Microtus ochrogaster in Kansas (Martin, 1956).

Studies have already been done on the role of daylight ratio (Lecyk, 1962 ;

* Present address : Laboratoire d'Histologie et Embryologie, Centre Hospitalier de Bicêtre, 78 avenue du Général-Leclerc, 94270 Le Kremlin-Bicêtre.

** Reprint requests to : L. Martinet. 
Bernard, 1964 ; Martinet, 1966) and the quality of the plants eaten (Martinet and Meunier, 1969 ; Martinet and Spitz, 1971) on the annual growth and reproduction cycle of the field-vole. Temperature is not the determining factor in the annual reproduction cycle of small, non-hibernating mammcls. However, it might play a role in seasonal variations of growth and reproduction in the field-vole.

In this work, we study the possible role of temperature, and of its interactions with the two factors already studied by Martinet and Meunier (1969) on growth and fertility in Microtus arvalis.

\section{Material and methods.}

Animals. From the day of birth, the cages containing the mothers and their pups were separated into different experimental groups. The female was given wood shavings and hay to make her nest, and at 14 days was taken from the cage. The pups were thus weaned, but may stay in the nest up to one month, at which time they were isolated.

Experimental groups. Twelve groups of animals were constituted according to a $3 \times 2 \times 2$ experimental design; they were raised under the following environmental conditions :

- three temperatures: $5^{\circ}, 22^{\circ}$ or $33^{\circ} \mathrm{C}$. During the experiment, temperatures varied in the first case between $3^{\circ}$ and $9{ }^{\circ} \mathrm{C}$, in the second case between $20^{\circ}$ and $25^{\circ} \mathrm{C}$ and in the third case between $28^{\circ}$ and $35^{\circ} \mathrm{C}$.

- two diets : spring or summer alfalfa. The alfalfa was cut at an early vegetative stage of growth $(30 \mathrm{~cm})$, either during the first vegetation cycle in april (spring alfalfa) or during the second vegetation cycle in june (summer alfalfa). It was ground and dried, then wetted again when distributed daily ad libitum. No other water was given.

- two daylight ratios : 15 L : $9 \mathrm{D}$ or $10 \mathrm{~L}: 14 \mathrm{D}$. Light level in the cages ranged between 200 and 300 lux.

Ambient humidity recorded throughout the experiment varied between 40 and 85 p. 100 at $5^{\circ}$, between 30 and 75 p. 100 at $22^{\circ}$, and between 40 and 45 p. 100 at $33^{\circ} \mathrm{C}$.

Growth. The litters were weighed at birth and again at 7, 14 and 21 days. The animals were then weighed individually when killed.

Fertility. The females were killed at 35 days, $48 \mathrm{~h}$ after intraperitoneal injection of $1.25 \mathrm{IU}$ of HCG. The number of ovulations was determined by examination of histological sections of each ovary.

The males were killed at 45 days and the testes and seminal vesicles weighed. The epididymes were ground and epididymal stocks estimated by spermatozoid count using a hematimeter.

Statisfical analysis. Mean weights of body and testes, or number of ovulations, were compared by multifactorial variance analysis. The number of females ovulating after HCG injection was compared using the $\chi^{2}$ test. 


\section{Result.}

Body growth.

Effect of temperature : from birth to 3 weeks, the higher the temperature, the slower the growth (fig. 1). This unfavorable effect of high temperature on growth is observed at 35 days again in females and at $\mathbf{4 5}$ days in males in groups raised under
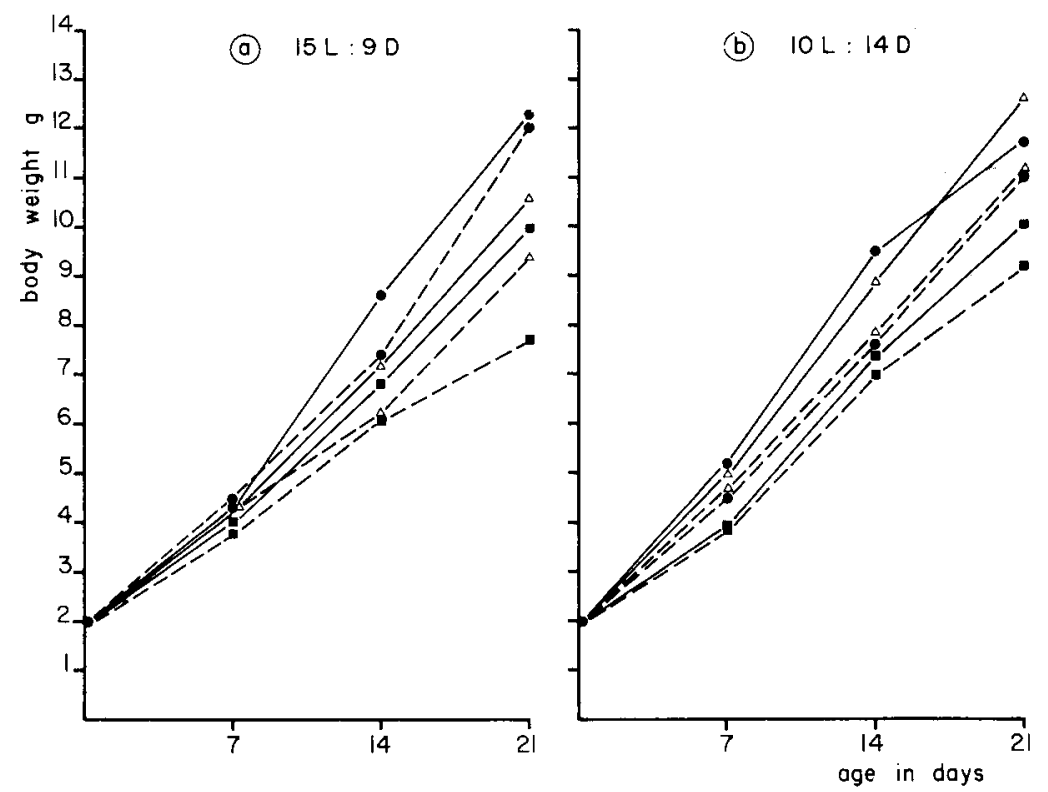

FIG. 1. - Effect of temperature, quality of alfalfa eaten and daylight ratio on body growth from birth to three weeks.

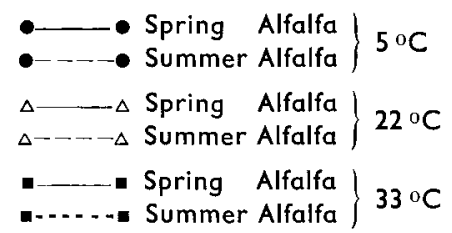

a $15 \mathrm{~L}: 9 \mathrm{D}$ daylight ratio ; body weight is significaritiy lower at $33^{\circ}$ than at $22^{\circ} \mathrm{C}$, and at $22^{\circ}$ than at $5{ }^{\circ} \mathrm{C}$ (figs. 2, 3). In animals raised under a $10 \mathrm{~L}: 14 \mathrm{D}$ daylight ratio the unfavorable effect of heat disappears after the age of 3 weeks, probably due to the highly significant interaction between these two factors. In males, body weight at 45 days is identical at $5^{\circ}, 22^{\circ}$ or $33^{\circ} \mathrm{C}$ (fig. 2) ; female body weight at 35 days is significantly lower at $33^{\circ}$ than at $5^{\circ} \mathrm{C}$ (fig. 3).

Effect of season of alfalfa harvest : up to 3 weeks, growth is slower in field-voles fed summer alfalfa than in those given spring alfaya (fig. 1). This unfavorable effect of summer alfalfa on growth still persits at 35 days in females and at 45 days in males 
in groups under a $15 \mathrm{~L}: 10 \mathrm{D}$ daylight ratio. On the other hand, in groups under a $10 \mathrm{~L}: 14 \mathrm{D}$ daylight ratio, animal weight is the same, whatever the diet.

Effect of daylight ratio : no definite effect of this factor is shown. The only observation we made is that the largest animals were those in the groups raised at $5{ }^{\circ} \mathrm{C}$ under $15 \mathrm{~L}: 10 \mathrm{D}$ daylight ratio.

Male fertility (fig. 2). Effect of temperature on spermatogenesis and the testis endocrine function depends on the daylight ratio. In animals raised under $15 \mathrm{~L}: 9 \mathrm{D}$ daylight
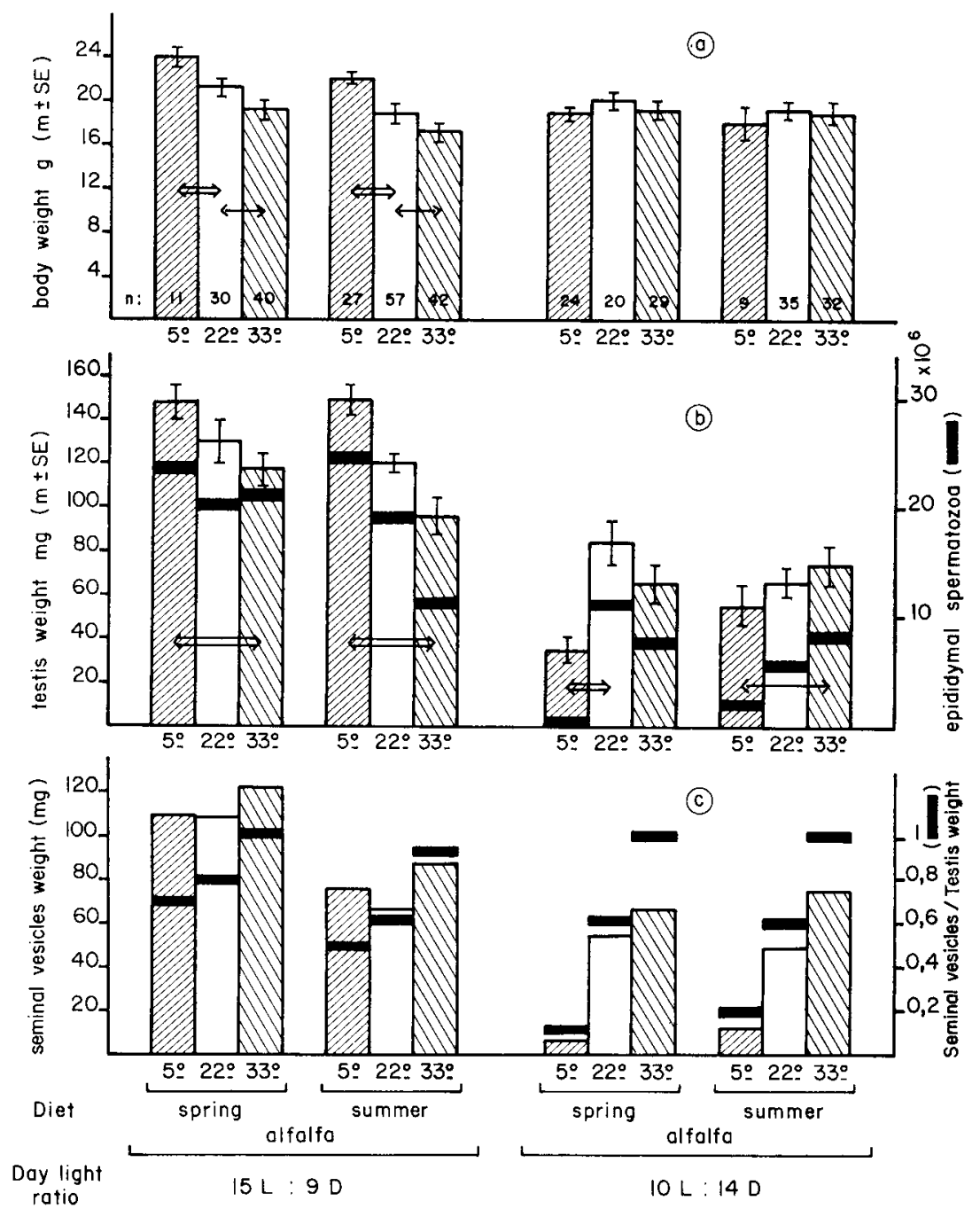

FIG. 2. - Effect of temperature, quality of alfalfa eaten and daylight ratio on :

a) male weight at 45 days,

b) weights of testes and epididymal stocks,

c) seminal vesicle weight and the ratio seminal, vesicle weight/testis weight. 
ratio, the testis weight and the number of epididymal spermatozoa decrease when the temperature rises. Seminal vesicle weight is unaffected. On the other hand, in animals raised under a $10 \mathrm{~L}: 14 \mathrm{D}$ daylight ratio, the weight of testes and seminal vesicles and the number of epididymal spermatozoa increase as the temperature rises. In all cases, the ratio seminal vesicle weight/testis weight increases concurrently with the temperature.

The qualify of plants eaten did not affect animal fertility.

Daylight ratio has considerable influence; the weight of testes and seminal vesicles and the number of epididymal spermatozoa are always significantly lower under a $10 \mathrm{~L}: 14 \mathrm{D}$ than under a $15 \mathrm{~L}: 9 \mathrm{D}$ daylight ratio.

Female fertility (fig. 3). The percentage of females ovulating after HCG injection is not changed by temperature, the quality of alfalfa eaten or daylight ratio. The number of ovulations in ovulated females seems to be controlled by these three factors, but the very wide variability within the same group makes the interpretation of results difficult.
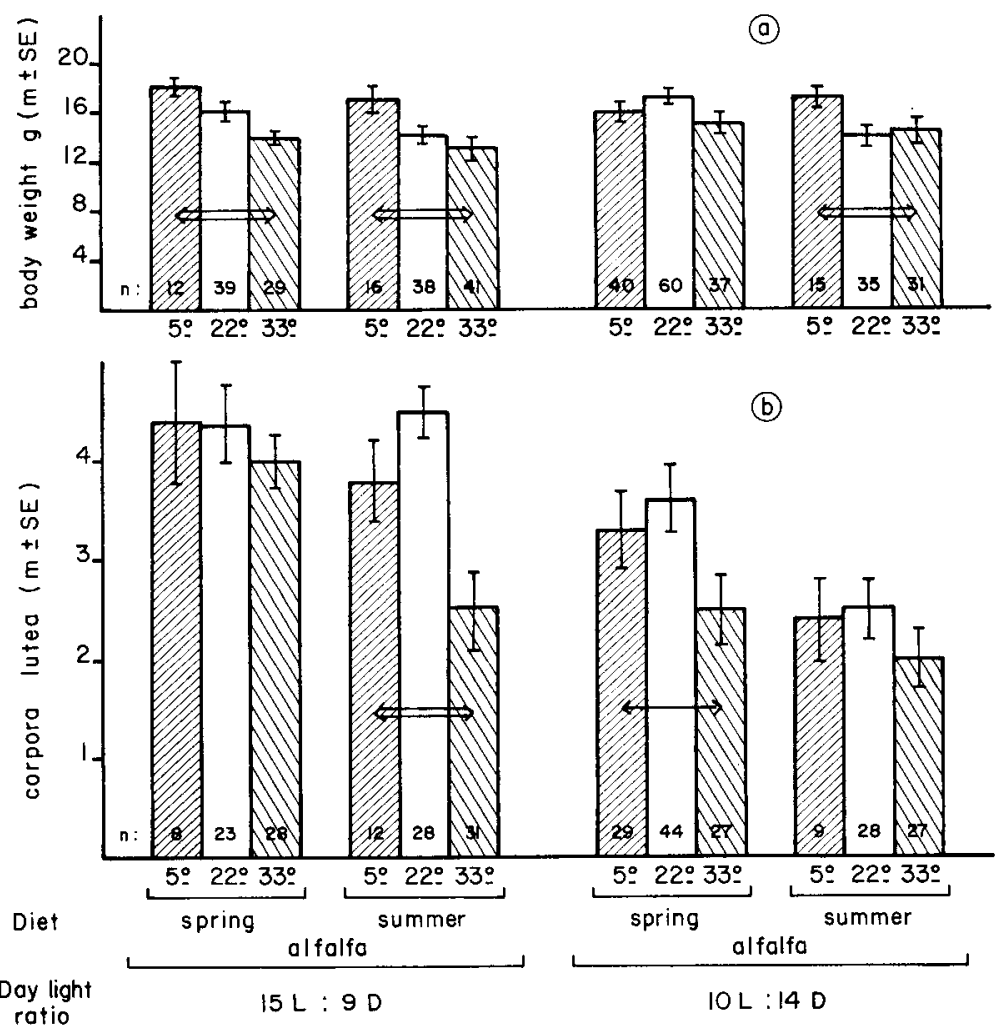

FIG. 3. - Effect of temperature, quality of alfolfa eaten and daylight ratio on :

a) female body weight at 35 days,

b) ovulation rate. 
Effect of temperature : in 2 out of 4 groups, at $33^{\circ} \mathrm{C}$ temperature has an unfavorable effect on the number of ovulations. The difference is not significant.

Effect of quality of plants eaten : the number of ovulations per female is usually lower in the group fed summer alfalfa than in those given spring alfalfa. However, this effect is only significant in the groups raised at $33^{\circ} \mathrm{C}$ under a $15 \mathrm{~L}: 9 \mathrm{D}$ daylight ratio or at $5^{\circ}$ and $22^{\circ} \mathrm{C}$ under a $10 \mathrm{~L}: 14 \mathrm{D}$ light ratio (fig. 3 ).

Effect of daily daylength : the mean number of ovulations is always higher in females roised under a $15 \mathrm{~L}: 9 \mathrm{D}$ light ratio, except in the $15 \mathrm{~L}: 9 \mathrm{D} 33^{\circ}$ groups.

\section{Discussion.}

Environmental temperature thus does not play a large part in the growth and reproduction cycles of the field-vole, Microtus arvalis. However, some effects are observed:

- Raising the temperature retards growth; this has already been described in rat and mouse (Pennycuik, 1966a ; Roubicek and Theurer, 1967). The reduction of weight gain is probably due to a decrease in food intake which is reduced by onehalf in the field-vole when the temperature is raised from $5^{\circ}$ to $22^{\circ} \mathrm{C}$ (Caillol and Martinet, 1976). Similar data have been noted in the mouse between $21^{\circ}$ and $34^{\circ} \mathrm{C}$ (Pennycuik, 1971) and in rabbit between $10^{\circ}$ and $30^{\circ} \mathrm{C}$ (Prud'hon, 1976). The retarded growth observed under higher temperatures may also be caused by reduction of the maternal milk yield when the mother is put under different experimental temperatures during lactation. Temperatures higher than $30^{\circ} \mathrm{C}$ retard the onset of lactation and decrease the amount of secretory tissue in the mouse (Knudsen, 1962 ; Pennycuik, 1966b).

TABLE 1

Analysis of male and female weights as related to favorable or unfavorable factors

\begin{tabular}{|c|c|c|c|}
\hline \multirow{2}{*}{ Favorable factors } & \multirow{2}{*}{ Unfavorable factors } & \multicolumn{2}{|c|}{ Body weight } \\
\hline & & Males & Females \\
\hline & su $* 33^{\circ} \mathrm{C}$ & $\begin{array}{l}17,4 \\
18,8\end{array}$ & $\begin{array}{l}12,9 \\
14,6\end{array}$ \\
\hline $\begin{array}{r}22^{\circ} \mathrm{C} \\
22^{\circ} \mathrm{C} \\
5^{\circ} \mathrm{C} \\
5^{\circ} \mathrm{C}\end{array}$ & $\begin{array}{l}\text { su } \\
\text { su } \\
\text { su } \\
\text { su }\end{array}$ & $\begin{array}{l}18,6 \\
19,0 \\
18,2 \\
22,0\end{array}$ & $\begin{array}{l}14,1 \\
14,1 \\
17,0 \\
17,4\end{array}$ \\
\hline $\begin{array}{l}\mathrm{sp}{ }^{* *} \\
\mathrm{sp}\end{array}$ & $\begin{array}{l}33^{\circ} \mathrm{C} \\
33^{\circ} \mathrm{C}\end{array}$ & $\begin{array}{l}19,3 \\
19,2\end{array}$ & $\begin{array}{l}14,3 \\
15,0\end{array}$ \\
\hline $\begin{array}{l}\text { sp } 22^{\circ} \mathrm{C} \\
\text { sp } 22^{\circ} \mathrm{C} \\
\text { sp } 5^{\circ} \mathrm{C} \\
\text { sp } 5^{\circ} \mathrm{C}\end{array}$ & & $\begin{array}{l}20,0 \\
21,2 \\
19,0 \\
24,0\end{array}$ & $\begin{array}{l}17,3 \\
15,7 \\
16,4 \\
17,9\end{array}$ \\
\hline
\end{tabular}

$*$ su $=$ summer alfalfa

** $s p=$ spring alfalfa. 
- When the temperature is raised, male and female fertility, measured by the number of gametes produced, decreases in animals kept under a $15 \mathrm{~L}: 10 \mathrm{D}$ daylight ratio. The same effect is seen in the redback vole (Roth, 1974). However, Clarke and Kennedy (1967) found no temperature effect on testis weight in Microfus agrestis. In the boar, a $16 \mathrm{~L}: 8 \mathrm{D}$ daylight ratio has a detrimental effect on spermatozoa quality if associated with a high ambient temperature of $35^{\circ} \mathrm{C}$. This effect does not appear with an ambient temperature of $25^{\circ} \mathrm{C}$ (Mazzari and al., 1968).

- The unfavorable effect of high temperature on the growth and fertility of the field-vole is only noted in animals raised under a $15 \mathrm{~L}: 10 \mathrm{D}$ daylight ratio. In subjects raised under short daylength, the unfavorable effect of high temperature on growth disappears after the age of 3 weeks; seminal vesicle weights even increase concurrently with the increase in temperature. These somewhat contradictory results can perhaps be explained by the significant interaction of temperature effect and daylight ratio.

- The role of daylight ratio and of the quality of plants eaten already noted in previous studies (Martinet and Meunier, 1969 ; Martinet and Spitz, 1971), appears again in this report, i. e. retarded growth and decrease in the number of gametes produced when the daylength diminishes or when the animals are fed alfalfa harvested later in the year.

No one of the three factors alone can explain the seasonal cycles of growth and reproduction in the field-vole. However, if the effects of factors favorable or unfavorable to body and gonad growth are added, these cycles may be explained. The data gathered in this study are shown in tables 1 and 2 . They are grouped according to

TABLE 2

Analysis of testis weight and number of ovulations as related to favorable or unfavorable factors

\begin{tabular}{|c|c|c|c|c|c|c|}
\hline \multicolumn{3}{|c|}{ Favorable factors } & \multicolumn{2}{|c|}{ Unfavorable factors } & \multirow{2}{*}{ Testis weight } & \multirow{2}{*}{$\begin{array}{c}\begin{array}{c}\text { Number of } \\
\text { ovulations }\end{array} \\
2,4\end{array}$} \\
\hline & & & $10 *$ & su $* 33^{\circ} \mathrm{C}$ & & \\
\hline & & $\begin{array}{r}5^{\circ} \mathrm{C} \\
22^{\circ} \mathrm{C}\end{array}$ & $\begin{array}{l}10 \\
10\end{array}$ & $\begin{array}{l}\text { su } \\
\text { su }\end{array}$ & $\begin{array}{l}55 \\
68\end{array}$ & $\begin{array}{l}2,3 \\
2,5\end{array}$ \\
\hline \multicolumn{3}{|c|}{$15 * * s p^{* *}$} & 10 & $\begin{array}{l}33^{\circ} \mathrm{C} \\
\text { su } \quad 33^{\circ} \mathrm{C}\end{array}$ & $\begin{array}{l}65 \\
95\end{array}$ & $\begin{array}{l}2,5 \\
2,5\end{array}$ \\
\hline & $\begin{array}{l}\text { sp } \\
\text { sp }\end{array}$ & $\begin{array}{r}5 \circ \mathrm{C} \\
22^{\circ} \mathrm{C}\end{array}$ & $\begin{array}{l}10 \\
10\end{array}$ & & $\begin{array}{l}35 \\
85\end{array}$ & $\begin{array}{l}3,2 \\
3,6\end{array}$ \\
\hline $\begin{array}{l}15 \\
15 \\
15\end{array}$ & & $\begin{array}{r}22^{\circ} \mathrm{C} \\
5^{\circ} \mathrm{C}\end{array}$ & & $\begin{array}{l}\text { su } \\
\text { su } \\
\text { su }\end{array}$ & $\begin{array}{l}118 \\
120 \\
150\end{array}$ & $\begin{array}{l}4,0 \\
4,6 \\
4,6\end{array}$ \\
\hline $\begin{array}{l}15 \\
15\end{array}$ & $\begin{array}{l}\text { sp } \\
\text { sp }\end{array}$ & $\begin{array}{r}22{ }^{\circ} \mathrm{C} \\
5 \circ \mathrm{C}\end{array}$ & & & $\begin{array}{l}130 \\
148\end{array}$ & $\begin{array}{l}4,4 \\
4,4\end{array}$ \\
\hline
\end{tabular}

$*$ su $=$ summer alfalfa

** sp $=$ spring alfalfa

* $10=10 \mathrm{~L}: 14 \mathrm{D}$

**15=15L: $9 \mathrm{D}$ 
favorable or unfavorable factors. It can be seen that the more favorable factors there are, the more rapid the growth and the higher the fertility.

The role of the environment on an animal or on a physiological function must be explained by the multiple synergic or antagonistic effects of many environmental factors.

Reçu en février 1977. Accepté en mars 1977.

Résumé. Les effets de 3 températures $\left(5^{\circ} \mathrm{C}, 22^{\circ} \mathrm{C}\right.$ ou $\left.33^{\circ} \mathrm{C}\right)$ et leurs interactions avec la durée quotidienne d'éclairement ( $15 \mathrm{~h}$ ou $10 \mathrm{~h}$ par $24 \mathrm{~h}$ ) et la date de récolte de la luzerne consommée (avril ou juin) ont été mesurés sur la croissance et la fertilité du campagnol mâle et femelle de la naissance à 45 jours.

La croissance corporelle et la fertilité diminuent en relation inverse avec la température. A l'effet défavorable d'une température ambionte chaude s'ajoute l'effet défavorable d'une photopériode quotidienne courte de $10 \mathrm{~h}$ sur la fertilité et d'une luzerne récoltée plus tardivement au cours de l'année sur la croissance corporelle et la fertilité.

A 35 jours pour les femelles et 45 jours pour les mâles, les individus les plus gros et les plus fertiles sont ceux élevés à $5{ }^{\circ} \mathrm{C}$ sous une photopériode claire longue de $15 \mathrm{~h}$ et nourris avec de la luzerne récoltée en avril ; au contraire les individus les plus petits ef les moins fertiles ont été élevés à $33^{\circ} \mathrm{C}$ sous une photopériode claire courte de $10 \mathrm{~h}$ et nourris avec de la luzerne récoltée en juin.

Les effets cumulatifs de ces 3 facteurs peuvent expliquer les cycles de croissance et de reproduction décrits précédemment.

\section{References}

BERNARD J., 1964. Note préliminaire sur la reproduction chez le campagnol des champs, Microtus arvalis Pall., dans le Sud de la Belgique. Bull. Inst. agron. Stat. Rech., Gembloux, 32, 275-289.

BODENHEIMER F. S., 1949. Problems of vole populations in the middle east. Report on the population dynamics of the levant vole. Res. Counc. Israel, 5-77.

CAILLOL M., MARTINET L., 1976. Effect of temperature on food, nitrogen and energy intake and assimilation in the field-vole, Microtus arvalis. Ann. Biol. onim. Bioch. Biophys., 16, 783-790.

CLARKE J. R., KENNEDY P. J., 1967. Effect of light and temperature upon gonad activity in the vole (Microtus agrestis). Gen. comp. Endocr., 8, 474-488

DELOST P., 1955. Etude de la biologie sexuelle du campagnol des champs (Microtus arvalis Pallas). Arch. Anat. micro. Morph. exp., 44, 150-190.

GREENWALD G. S., 1957. Reproduction in a coastal California population of the field mouse Microtus Californicus. Univ. Calif. Publ. Zool., 54, 421-446.

KNUDSEN B., 1962. Growth and reproduction of house mice at 3 different temperatures. Oikos, 13, 1-14.

LECYK M., 1962. The effect of the length of daylight on reproduction in the field-vole (Microtus arvalis). Zool. Pol., 12, 189-221.

MARTIN E. P., 1956. A population study of the prairie vole (Microtus Ochrogaster) in northeastern Kansas. Univ. Kans. Publ. Mus. Nat. hist., 8, 361-416.

MARTINET L., 1966. Modification de la spermatogenèse chez le campagnol des champs (Microtus arvalis) en fonction de la durée quotidienne d'éclairement. Ann. Biol. anim. Bioch. Biophys., 6, 301-313.

MARTINET L., 1967. Cycle saisonnier de reproduction du campagnol des champs Microfus arvalis. Ann. Biol. anim. Bioch. Biophys., 7, 245-260. 
MARTINET L., MEUNIER M., 1969. Influence des variations saisonnières de la luzerne sur la croissance, la mortalité et l'établissement de la maturité sexuelle chez le campagnol des champs (Microlus arvalis). Ann. Biol. anim. Bioch. Biophys., 9, 451-462.

MARTINET L., SPITZ F., 1971. Variations saisonnières de la croissance et de la mortalité du campagnol des champs, Microfus arvalis. Rôle du photopériodisme et de la végétation sur ces variations. Mammalia, 35, 38-84.

MAZZARI G., du MESNIL du BUISSON F., ORTAVANT R., 1968. Action de la température et de la lumière sur la spermatogenèse, la production ef le pouvoir fécondant du sperme chez le verrat. Vle Congr. intern. Reprod. anim. Insém. ortif., Paris, Vol. I, 305-308.

PENNYCUIK P. R., 1966a. Factors affecting the survival and growth of young mice born and reared at 360. Austr. J. exp. Biol. med. Sci., 44, 405-418.

PENNYCUIK P. R., 1966b. Differences between mice gestating and lactating at $21^{\circ}$ and at $34^{\circ}$ with particular reference to the mammary gland. Austr. J. exp. Biol. med. Sci., 44, 419-438.

PENNYCUIK P. R., 1971. Seasonal changes in reproductive productivity, growth rate and food intake in mice exposed to different regimes of daylength and environmental temperature. Aust. J. biol. Sci., 25, 627-635.

PRUD'HON M., 1976. Comportement alimentaire du lapin soumis aux températures de 10, 20 ou $30^{\circ} \mathrm{C}$. $1^{\mathrm{er}}$ Congr. int. Cunicole, Dijon, 31 mars-2 avril 1976.

RAYNAUD A., 1951. Reproduction en hiver des campagnols agrestes dans le département du Tarn. Bull. Soc. Zool., France, 76, 188-200.

ROTH R. R., 1974. The effect of temperature and light combinations upon the gonads of male redback voles. Biol. Reprod., 10, 309-314.

ROUBICEK C. B., THEURER C. B., 1967. The effect of high environmental temperature on growth and body compositions of rats. Growth, 31, 369-374.

STEIN G. H. W., 1952. Uber Massenmehrung und Massenzusammenbruck bei der Feld-maus. III. Microtus arvalis. Zool. Jahrbüch. Syst. Okol., 81, 1-26. 